\title{
CHOOSING EXOTIC OVER THE FAMILIAR TASTE: HABITAT-SPECIFIC PREFERENCES OF A MALACOPHAGOUS LEECH FOR FRESHWATER SNAILS AS PREY
}

\author{
Pranesh Paul, Rupsha Karmakar, Gautam Aditya* \\ Department of Zoology, University of Calcutta, 35, Ballygunge Circular Road, Kolkata - 700019
}

Abstract.

The spread of freshwater invasive species through aquarium trade poses a threat to the ecosystem, economy and human health. The availability of the exotic freshwater gastropod mollusc, Planorbarius corneus (Linnaeus, 1758) (Gastropoda: Planorbidae), in pet shops in Kolkata, West Bengal, India, raises concern for its potential establishment as an invasive species. Assuming the role of the native predators as a potential biotic barrier for invasion, observations on the predation pattern of the malacophagous leech, Glossiphonia weberi (Blanchard, 1897) (Clitellata: Glossiphoniidae) against P. corneus was made in single as well as in combination with the native snail Indoplanorbis exustus (Deshayes, 1834) (Gastropoda: Planorbidae). Using varying size classes and densities of $\mathrm{P}$. corneus, the predation potential of $\mathrm{G}$. weberi was estimated after a 24 hour period. In another set of experiments, the predation of $\mathrm{G}$. weberi against the snail $\mathrm{P}$. corneus was observed in the presence of $\mathrm{I}$. exustus under four different habitat conditions. The purpose was to justify - (1) the effect of conspecific and heterospecific conditions of the prey availability and (2) the effect of habitat complexity on the predatory efficacy of $\mathrm{G}$. weberi. The results indicated that $\mathrm{G}$. weberi consumed varied numbers of $\mathrm{P}$. corneus, depending on the size and the densities of the prey and predator. Although the prey heterogeneity and complex habitats caused significant reduction of predation on both of the prey species, G. weberi significantly preferred $\mathrm{P}$. corneus over I. exustus in open $(\mathrm{P}<0.0001)$, macrophyte $(\mathrm{P}=0.002)$ and pebbles and macrophyte containing habitats $(\mathrm{P}<$ 0.0001). Apparently, G. weberi preferred the exotic snail P. corneus in presence of alternative prey snail I. exustus, under different habitat conditions. Therefore, G. weberi may act as a significant biotic resistance against the colonization and establishment of $\mathrm{P}$. corneus in the Indian context. However, further studies including the multiple prey and predators are required to ascertain the food web level impact of the exotic snail P. corneus in invaded freshwater ecosystems.

Key words: Invasive species; Planorbarius corneus; Indoplanorbis exustus; habitat complexity; Glossiphonia weberi; prey preference.

\section{INTRODUCTION}

In course of the dispersal beyond the native range, the invasive species can cause several direct and indirect effects on human health, local economy and the ecosystem by competing with (Human \& Gordon 1996; Dobson 2004) or predating upon the native species (Doherty et al. 2016), altering the community structure (Sanders et al. 2003; Gillis \& Chalifour 2010) and increasing the disease or pest load (Crowl et al. 2008; Hosokawa et al. 2014; Paini et al. 2016). Therefore, the invasive species cause significant damage in ecological communities (Grosholz 2002; Carlton 2003) and contemplated to be a major threat of biodiversity loss (Wilcove et al. 1998; Mack et al. 2000). For example, the invasive Argentine ant Linepithema humile successfully displaced a native ant species by interspecific competition in a biodiversity reserve of California (Human \& Gordon 1996). Besides competition, from the long-term observation, it is evident that in the freshwater lakes where the invasive predatory crayfish Orconectes rustics increased in number, vast decline occurred in the snail abundance (Kreps et al. 2012). Invasive animals do not only disrupt the faunal biodiversity, but they can also execute serious harm to native vegetations as observed for Pomacea canaliculata in the freshwater ecosystem (Carlsson \& Lacoursière 2005; Carlsson \& Brönmark 2006) and Achatina fulica in the terrestrial ecosystem (Raut \& Barker 2002).

Apart from natural reasons, human-mediated activities are often responsible for the invasion of various non-native freshwater species by breaking the geographical barriers of species distribution (Su et al. 2016). The increasing popularity of ornamental pet trade and aquaria are suspected to introduce non-native plants, gastropods, and fishes in different parts of the world (Rixon et al. 2005; Chang et al. 2009; Ng et al. 2016). The availability of diverse freshwater or- 
namental gastropods and bivalves in the pet shops as well as non-ornamental species present as fish food or hitchhikers, indicate a high risk of the spread, colonization and establishment of invasive species through aquarium trade ( $\mathrm{Ng}$ et al. 2016). Once established, the invasive species may displace the native snails and subsequently become abundant in the benthic communities, as observed for the snail Tarebia granifera, a freshwater snail introduced in South Africa (Miranda et al. 2011; Miranda \& Perissinotto 2014a, b). Although many aquatic snails feed primarily on detritus, algae and microscopic organisms, some groups of snails consumed fresh hydrophytes which can cause damages to the agricultural or economically beneficial plants (Estebenet 1995). For instance, Pomacea spp. were introduced from South America to the Southeast Asian countries as a potential protein source that escaped from aquaculture, and due to their high fecundity and quick growth these species established in natural habitats and turned into agricultural pests of rice fields and wetland floral vegetations (Cowie 2002; Carlsson \& Lacoursiere 2005; Kwong et al. 2008).

The freshwater gastropod Planorbarius corneus (Linnaeus, 1758) (Gastropoda: Planorbidae) is a much-admired ornamental snail (Seddon \& Van Damme 2011) and is commonly known as "the great ramshorn snail" among the aquarium enthusiasts. One of the interesting features that the planorbid snails possess is the presence of hemoglobin molecules in their hemolymph (Lieb et al. 2006). Because of the high hemoglobin content in the hemolymph of the snail $P$. corneus, they appear reddish to brown which makes this snail as an interesting aquarium pet. The snail P. corneus is generally found all over the European countries (Wesselingh et al. 1999; Seddon \& Van Damme 2011) and is sold as an ornamental snail in different parts of the world (Duggan 2010; Zhao 2013). In Kolkata, India, the gastropod P. corneus is sold in the aquarium pet shops and markets without any legal restriction or precautions (Parveen et al. 2019). Previous studies indicated that high fecundity (Costil \& Daguzan 1995a, b), rapid growth (Zotin 2018) and long life span (Berrie 1963) can facilitate the establishment of the exotic snail $P$. corneus in the freshwater habitats if released from such aquaria. Despite the small body size, P. corneus is a matter of great concern to the native ecosystem health, similar to other non-native gastropods as introduced before.

The establishment of the non-native species beyond their original geographic range depends on several biotic and physical factors. For instance, the chances of the establishment of invading species in a newer habitat can be reduced considerably by the native predator assemblages (Baltz \& Moyle 1993). In the Indian context, the malacophagous leeches and hemipteran insects are considered as effective predators of different native and exotic snails (Aditya \& Raut 2001, 2002a, b, c, 2004, 2005). Thus, in the present study, we employed the leech, Glossiphonia weberi (Blanchard, 1897) (Clitellata: Glossiphoniidae) as a potential native predator against the exotic snail $P$. corneus. The diet of glossiphoniid leeches largely consists of chironomid larvae, oligochaetes and snails (Young \& Ironmonger 1980; Raut \& Nandi 1984; Wilken \& Appleton 1991; Davies et al. 1997; Kutschera 2003; Krupski et al. 2018). In laboratory observations, G. weberi exhibited a preference for the non-operculate snails against the operculate snails found in the freshwater communities of West Bengal, India (Aditya \& Raut 2005). A non-operculate snail Indoplanorbis exustus (Deshayes, 1834) (Gastropoda: Planorbidae), which is passably morphologically similar to the non-native snail P. corne$u s$, was considered as an alternative prey. The native planorbid snail, I. exustus is common in different parts of India, including West Bengal, bearing significance in helminth disease transmission (Malek \& Cheng 1974; Biswas 1991; Sangwan et al. 2016) as well as multifunctional roles in the maintenance of the community structure functions (Raut 1981). Therefore, it would be appealing to study how native predatory $G$. weberi interact with non-native $P$. corneus prey when presented with native I. exustus prey in the same habitat.

Along with the biotic factors, physical factors also influence the prey-predator interaction. Among the physical factors, the physical arrangement of different habitat elements may vary between different habitats and create many microhabitats, which imply a significant influence on faunal composition and interactions between the prey and predators (Beukers \& Jones 1997; Grabowski 2004). Both the predator and the prey can benefit from the complexity of the habitat condition. The aquatic vegetation, pebbles, sediments or detritus can help the prey to refuge from the attack of predators and thus result in a decrease of predation rate. For example, the leaves of sea-grass protect the small fishes and shellfishes from the attack of predators (Stoner 1982; Harris et al. 2004). The predator can also be benefited from the complex 
structure of habitats as the complexity can obstruct the movement or reduce the visual field of the prey (Rilov et al. 2007). The structural complexity of the habitat allows the predator to choose an attacking position that is otherwise impossible in simple habitats (Giller \& McNeill 1981). As an extension to these observations, in the present instance, the habitat conditions and alternative prey were considered as the factors influencing the predation pattern of the leech $G$. weberi. The purpose of the experiments was to evaluate the prospective role of the leech $G$. weberi in population regulation of the exotic snail $P$. corneus. The choice of the predator G. weberi between native and exotic snails was judged through its quest for the prey in the background of complex habitat conditions. The results are expected to provide an insight into the prey selection pattern of the malacophagous leech and highlight its potential as a biological barrier to the colonization and establishment of the snail P. corneus.

\section{Materials ANd Methods The Predator}

The malacophagous leech $G$. weberi $(G W E)$, used in this study as a predator were collected from the pond in the Ballygunge Science College campus, University of Calcutta, Kolkata, India throughout the experiment. The pond in reference was a perennial water body with characteristic dominance of Alternanthera philoxeroides, Jussiaea repens and Pistia stratiotes in succession throughout the year with the presence of sparse numbers of Lemna minor, Wolffia globosa, and Spirodella sp. Along with the occasional removal of the vegetation, the fluctuation of the water levels over the seasons in a year, results in the variable number of macroinvertebrate species and the fish in the concerned pond. The freshwater snails including I. exustus, various predatory and non-predatory Hemiptera, larval and adult Coleoptera, larval Odonata and Ephemeroptera among insects, crustaceans and Oligochaeta are common macroinvertebrates observed with few species of small indigenous fish species. The leeches were picked from decaying submerged leaves by using soft brushes and transferred to glass aquaria $(\sim 15 \times 15 \times 15 \mathrm{~cm}$ dimension of a glass aquarium). The leeches were maintained in tap water in the laboratory and fed with snails ad libitum until they were used in experiments. The snails Lymanea luteola (4-8 $\mathrm{mm}$ in shell length) (Raut and Nandi 1984) were provided as food for the rearing of the leeches at a density of 25 per aquarium. During rearing in the laboratory, the water of the glass aquaria was changed daily and the shells of dead snails, remains of dead snails and dead leeches (if any) were removed to maintain the water quality. The length of the leeches was measured using a vernier caliper (Insize, Brazil) to the nearest $0.1 \mathrm{~mm}$ at their resting condition and leeches belonging to the size class $8-9 \mathrm{~mm}$ were selected for the experiment as this was the most abundant size class in the collections. Before their use in the experiment, the leeches were fed with snails to satiation and then kept in starvation for 24 hours.

\section{The Prey}

The non-native snail $P$. corneus (PCO) was brought from a local pet market in Kolkata, India, as and when required for the experiment. The culture of $P$. corneus was maintained at a density of 20 per 1 of water, with lettuce as the food resource in plastic tubs $(32 \times 26 \times 10 \mathrm{~cm}$, Tarsons, India), filled with at least 5 liters of tap water. As a result of continued breeding in the laboratory as well as the collection of the snails from the pet market a heterogeneous population of different size classes was obtained and further reared in the laboratory. Another prey, I. exustus (IEX) was collected using a sampling net of $200 \mu \mathrm{m}$ mesh size and brought to the laboratory from ponds present around Kolkata, West Bengal, India and maintained in laboratory conditions in glass aquarium at a density of 20 per 1 in a plastic tub $(32 \times 26 \times 10 \mathrm{~cm}$, Tarsons, India), filled with at least 5 liters of water, as and when required for the experiments. Until their use in the experiment, they were fed with lettuce ad libitum and the water of aquaria was changed at regular intervals to remove fecal matter and unconsumed food. For both the prey snails, the segregation based on the size classes was made prior to their use in the experiments.

\section{Experimental Design}

Experiment I: The first experiment was performed to find out the predatory potential of $G$. weberi on $P$. corneus. The snails were divided into three separate groups $(2-4 \mathrm{~mm}, 5-7 \mathrm{~mm}$, and $8-10 \mathrm{~mm})$ based on shell diameter. For all size classes, three different prey densities were created, i.e. $\mathrm{n}=5,10$, 20 snails per group. The snails were placed in plastic containers having a volume of $2000 \mathrm{ml}$. In every type of containers with different prey densities, different numbers of predatory leeches were introduced, i.e. 
$\mathrm{n}=1,2$ and 4 , to quantify the effect of predator density on prey consumption. This experiment was replicated for 48 times.

Experiment II: In this experiment, the predatory potential of $G$. weberi was observed under two different conditions, heterospecific prey species combination and habitat structural complexity. Based on prey consumption, the preference for a particular prey species by $G$. weberi was judged under these conditions. For this experiment, we used three combinations of prey, i.e. P. corneus: I. exustus $=5: 5,10: 0$ and 0:10. In the first combination, 5 individuals of both prey species were added, i.e. the heterospecific condition, and in the last two combinations, i.e. conspecific condition of prey, 10 individuals of only one prey species were added in the plastic containers having the capacity of $2000 \mathrm{ml}$. For this experiment, the selected size class was $5-7 \mathrm{~mm}$ for both prey species, and one individual of $G$. weberi was added in all experimental containers. To determine the effect of the structural complexity of habitats on the predation rate of $G$. weberi, four different types of habitat were created:

a) Open $(\boldsymbol{O})$ : This habitat type had no structural complexity as the plastic containers held only water.

b) Macrophyte complexity (M): In this habitat type, five leaves of Vallisneria spiralis were added vertically to the water surface to add more complexity than open habitat.

c) Pebbles complexity $(\boldsymbol{P})$ : Different sizes of pebbles $(5-15 \mathrm{~mm})$ were spread as a monolayer in the bottom of the plastic container without changing the water volume.

d) Macrophyte and pebbles complexity (MP): Both pebbles and leaves of $V$. spiralis were added to create a more complex habitat.

The second experiment was repeated for 50 times. All experiments were carried out in the temperature $25 \pm 1^{\circ} \mathrm{C}$, and photoperiod of 16:8 hours. The numbers of prey consumed in all replicates were noted at the end of 24 hours. The continued availability of the prey snails and the collection of the leeches ensured that a predator or prey was used only once in a trial in compliance with the norms of replication (Hurlbert 1984).

\section{Data Analysis}

To ascertain if different prey and predator density influenced the consumption rate of $G$. weberi on P. corneus, a univariate analysis of variance (ANO-
VA) followed by Fisher least significant difference (LSD) tests (Zar 1999) were applied. The data was initially subjected to the assessment of homogeneity of variance using Levene's test. If required, a $\log (\mathrm{x}+1)$ transformation was made for the data and further Levene's test of homogeneity of variance and Welch's robust test of equality of means were applied to judge the compliance of the data for the application of ANOVA. Descriptive statistics were calculated for all experimental combinations to find out the mean predation rate/24 hours. To justify the effects of habitat complexity and the species heterogeneity on the predation rate of $G$. weberi on both $P$. corneus and $I$. exustus, a logistic regression was used. Assuming a generalized linear model (GLM) the data on the prey consumption under prey conditions and habitat complexity were subjected to the binomial generalized linear model with logit link. In this form of logistic regression, the prey consumption in the response variable (y) and the explanatory variables and are the prey condition, $\mathrm{x}_{1}$ (heterospecific or conspecific) and the habitat complexity $\left(\mathrm{x}_{2}\right)$, taking the equation to the form of: Prey consumed $(y)=1 /(1+\exp (-(-\mathrm{a}$ $+\mathrm{b} 1 \mathrm{x} 1+\mathrm{b} 2 \mathrm{x} 2)))$, with a as intercept and $\mathrm{b}$ as slope. The data on consumption was weighted so that the data takes the form of a proportion with the underlying assumption that the response variable 'prey consumption' follows a binomial (n, p) distribution with $\mathrm{n}$ being the replicates for each of the linear combination (p) of the explanatory variables (prey condition and the habitat conditions). A logit link was used and the model parameters were deduced through maximum likelihood using the software XLSTAT (Addinsoft 2010). For each value of estimated parameters the significance was justified through a Chi square value. The assessment was made for P. corneus and I. exustus as prey, separately.

Further, to determine if any significant prey preference or avoidance exists, the numbers of $P$. corneus and I. exustus consumed by G. weberi were analyzed for the index of selectivity (Chesson 1978). The following equation was used to calculate the selectivity index:

$$
\alpha_{i}=\frac{c_{i}}{n_{i}} / \sum_{1}^{n} \frac{c_{j}}{n_{j}}
$$

Where, $\alpha_{i}=$ selectivity index for P. corneus or I. exustus, $c_{i}=$ number of $P$. corneus or $I$. exustus consumed, $n_{i}=$ abundance of $P$. corneus or $I$. exustus, $c_{j}=$ total 
number of prey consumed and $n_{j}=$ abundance of total prey in the experimental setup. The final values of the selectivity index $(\mathrm{Si})$ for the respective prey species were standardized between the ranges $0-1$ by the following equation (Rehage et al. 2005):

$$
S_{i}=\alpha_{i} / \sum \alpha_{i}
$$

In this experiment, as the number of prey species is two, values of $S_{i}$ lower than 0.5 indicate relative avoidance and greater than 0.5 indicate a relative preference by the predator. One sample t-test at the alpha $=0.05$ level was applied to determine if the $S_{i}$ value significantly differs from 0.5 . ANOVA and t-tests were conducted using a licensed copy of $X L$ STAT version 2010.04.02 (Addinsoft 2010) and SPSS ver 16.

\section{RESUlts}

Experiment I. The observed predation pattern of $G$. weberi remained similar on $P$. corneus as on the other snails (Aditya \& Raut 2005) (Figure 1a-d). The consumption of $P$. corneus by malacophagous G. weberi varied from $0.250 \pm 0.063$ (mean $\pm \mathrm{SE}$ ) to $1.937 \pm 0.137$ with the changing density of prey and predators and size classes of prey (Table 1). The result of ANOVA (Table 2) exhibits that predator density, prey density and prey size have a significant effect (alpha at $5 \%$ ) on the prey consumption by $G$. weberi $(\mathrm{N}=1296$ observations; 3 levels of predator density, 3 levels of prey density, 3 levels of prey size classes $=27 * 48$ replicates for each combination). To assess the homogeneity of variance, Levene's test was applied to the data on the snail prey consumed. Since the Levene's test $(\mathrm{W}=5.939$, df $=26,1269 ; \mathrm{P}<0.001)$ remained significant, the data on prey consumption were $\log (\mathrm{x}+1)$ transformed and further Levene's test was performed along with the Welch's robust test for the equality of means. The tests were carried out in SPSS ver. 16 software and in each instance a single explanatory variable was considered. The log-transformed data complied with the norms of homogeneity of variance for the predator density (Levene's test, $W=0.586, d f=2,1293 ; P=$ 0.205 ) and prey density (Levene's test, $W=0.732, d f$ $=2,1293 ; P=0.481)$ as explanatory variables but not with the prey size (Levene's test, $W=19.358$, $d f$ $=2,1293 ; P<0.001)$. In all instances, the Welch's robust test of equality of means remained significant (for predator density, Welch test $(T)=94.013$; $d f=2,857.85 ; P<0.0001$; for prey density, Welch

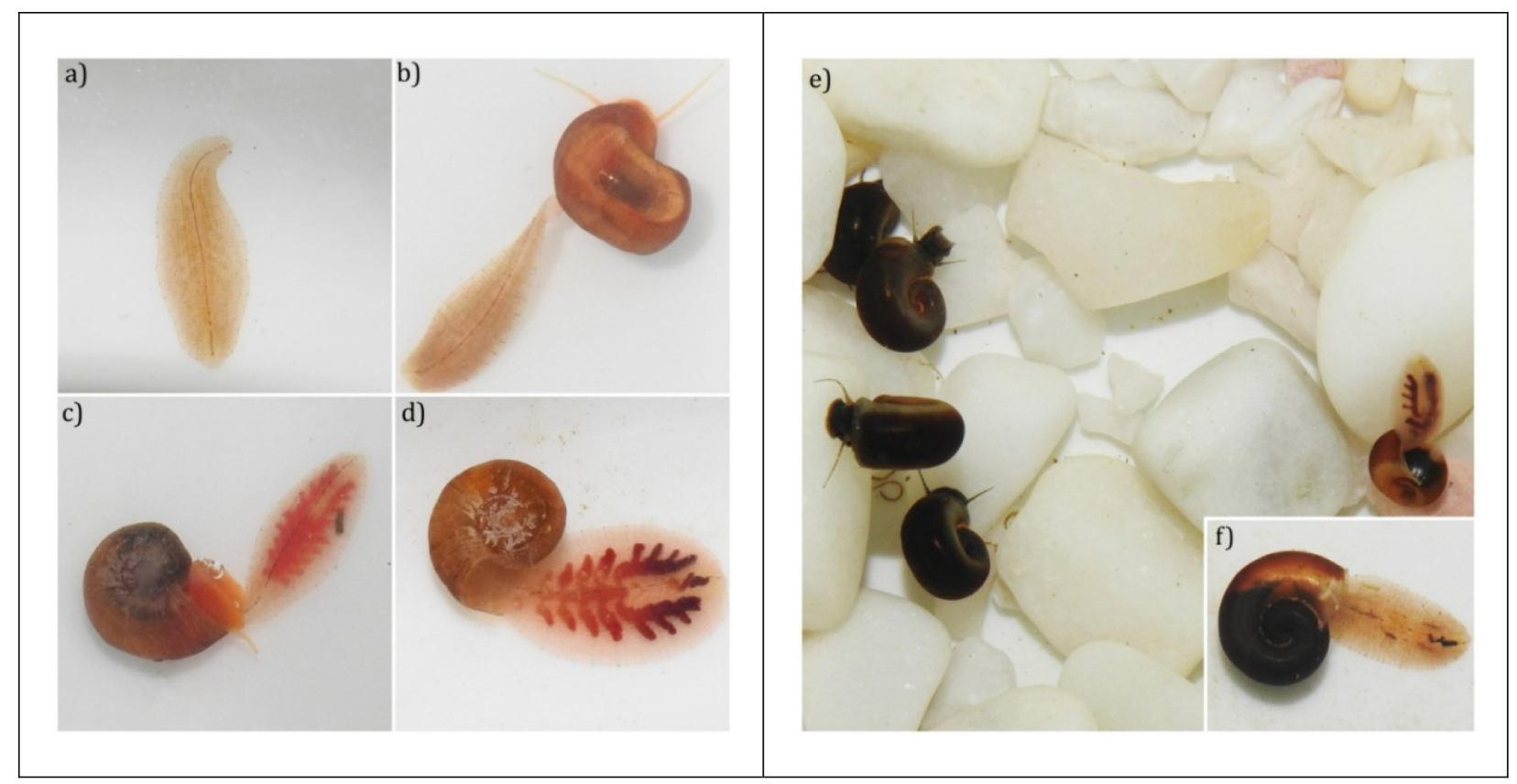

Figure 1 (a-d). The predatory behavior of the malacophagous leech, G. weberi on the exotic snail, P. corneus [(a) G. weberi waited for the prey and moved the anterior tip to different directions, (b) the leech attached the anterior sucker to the shell of $P$. corneus, (c) after repeated attempts, G. weberi succeed to capture the soft body part of $P$. corneus and (d) $G$. weberi fed on the captured prey until only the shell remained], (e) predation of $G$. weberi on dispersed I. exustus on the pebbles habitat and (f) consumption of I. exustus. 
Table 1: The prey consumption (mean $\pm \mathrm{SE}$ ) by the malacophagous leech $G$. weberi (GWE) in different relative numbers, at the end of 24 hour period, on the different density levels and size classes of the exotic snail P. corneus.

\begin{tabular}{|c|c|c|c|c|}
\hline \multirow{2}{*}{$\begin{array}{l}\text { Size class of } \\
\text { PCO }\end{array}$} & \multirow{2}{*}{$\begin{array}{l}\text { Prey density } \\
\text { (PCO) }\end{array}$} & \multicolumn{3}{|c|}{ Predator density (GWE) } \\
\hline & & $\mathbf{n}=\mathbf{1}$ & $\mathbf{n}=\mathbf{2}$ & $n=4$ \\
\hline \multirow{6}{*}{$\begin{array}{l}2-4 \mathrm{~mm} \\
\text { (A) }\end{array}$} & \multirow{2}{*}{$\mathbf{n}=\mathbf{5}$} & $0-3$ & $0-3$ & $0-4$ \\
\hline & & $0.812 \pm 0.117$ & $1.083 \pm 0.114$ & $1.541 \pm 0.115$ \\
\hline & \multirow{2}{*}{$\mathrm{n}=\mathbf{1 0}$} & $0-2$ & $0-3$ & $0-4$ \\
\hline & & $0.916 \pm 0.093$ & $1.291 \pm 0.126$ & $1.770 \pm 0.149$ \\
\hline & \multirow{2}{*}{$\mathbf{n}=\mathbf{2 0}$} & $0-3$ & $0-3$ & $0-4$ \\
\hline & & $0.979 \pm 0.081$ & $1.416 \pm 0.122$ & $1.937 \pm 0.137$ \\
\hline \multirow{6}{*}{$\begin{array}{l}\text { 5-7 mm } \\
\text { (B) }\end{array}$} & \multirow{2}{*}{$\mathbf{n}=\mathbf{5}$} & $0-1$ & $0-3$ & $0-3$ \\
\hline & & $0.562 \pm 0.072$ & $1.041 \pm 0.129$ & $1.187 \pm 0.113$ \\
\hline & \multirow{2}{*}{$\mathbf{n}=\mathbf{1 0}$} & $0-2$ & $0-3$ & $0-4$ \\
\hline & & $0.562 \pm 0.078$ & $1.291 \pm 0.111$ & $1.625 \pm 0.147$ \\
\hline & \multirow{2}{*}{$\mathbf{n}=\mathbf{2 0}$} & $0-2$ & $0-2$ & $0-4$ \\
\hline & & $0.541 \pm 0.083$ & $0.750 \pm 0.096$ & $1.333 \pm 0.146$ \\
\hline \multirow{6}{*}{$\begin{array}{l}\text { 8-10 mm } \\
\text { (C) }\end{array}$} & \multirow{3}{*}{$\mathbf{n}=\mathbf{5}$} & $0-1$ & $0-2$ & $0-3$ \\
\hline & & $0.250 \pm 0.063$ & $0.395 \pm 0.082$ & $1.125 \pm 0.121$ \\
\hline & & $0-1$ & $0-2$ & $0-4$ \\
\hline & $\mathbf{n}=\mathbf{1 0}$ & $0.354 \pm 0.069$ & $0.416 \pm 0.083$ & $1.166 \pm 0.123$ \\
\hline & \multirow{2}{*}{$\mathbf{n}=\mathbf{2 0}$} & $0-2$ & $0-2$ & $0-3$ \\
\hline & & $0.520 \pm 0.078$ & $0.604 \pm 0.082$ & $1.020 \pm 0.141$ \\
\hline
\end{tabular}

test $(T)=3.323 ; d f=2,861.864 ; P<0.04$; for prey size, Welch test $(T)=73.912 ; d f=2,861.185 ; P<$ $0.001)$ supporting that the mean values were different among the different levels of the explanatory variables. The log transformed data did reduce the extent of heterogeneity, as reflected through the Levene's test value $(W=3.507 ; d f=26,1269, P<0.0001)$. Thus the univariate ANOVA was carried out with the $\log (\mathrm{x}+1)$ transformed data followed by Fisher's least significant difference (LSD) as a post hoc comparison (Table 2). The mean consumption rates clearly indicate that the predation in all instances significantly decreases $(F=103.15, d f=2,1289 P<0.0001)$ as the prey increases in size (Table 2). Based on the F-value, it was apparent that the predator density bears a greater effect on the prey consumption, perhaps an indication of the predator interference, with the per capita consumption being higher at lower density. The trend remained the same for irrespective of prey density.
The result of Fisher's LSD test (Table 2) showed that all parameters have significant influences on predation rate except between prey density ten and twenty. Even though prey density had a significant effect on predation, no common trend in consumption rates with increasing density was followed in half of the cases, and in the rest, predation rates increased with increasing prey density. The mean consumption on P. corneus increased with predator density (Table 1), but the consumption/predator was negatively linked with density of predators, i.e., the prey consumption decreased with the increasing predator density at all levels of prey density except for the largest prey size class (Figure 2). Such variations can arise as a result of predator interference in case of high predator density, and the predator satiation for the large prey size.

Experiment II. The predation rate of G. weberi on both P. corneus and I. exustus changed with habitat complexity and prey heterogeneity from $0.18 \pm$ 
Table 2: The results of the univariate ANOVA and the post hoc Fisher's least significant difference (LSD) on the $P$. corneus consumption (log transformed data) by the malacophagous leech G. weberi using the predator density, prey density and the prey size as the explanatory variables. The values in bold indicate significant difference at least at $\mathrm{P}<$ 0.05 level. For prey size, A represents $2-4 \mathrm{~mm}$ of shell diameter, B represents $5-7 \mathrm{~mm}$, and C represents $8-10 \mathrm{~mm}$ shell diameter of the snails.

\begin{tabular}{lcccc}
\hline \multicolumn{1}{c}{ Source } & SS & DF & MS & F \\
\hline Predator density & 6.176 & 2 & 3.088 & $\mathbf{1 0 3 . 1 5 4}$ \\
Prey density & 0.252 & 2 & 0.126 & $\mathbf{4 . 2 1 7}$ \\
Prey size & 4.951 & 2 & 2.475 & $\mathbf{8 2 . 6 9 1}$ \\
Error & 38.586 & 1289 & 0.030 & \\
Total & 49.964 & 1295 & & \\
\hline
\end{tabular}

\begin{tabular}{|c|c|c|c|c|c|}
\hline & Contrast & Difference & $\begin{array}{c}\text { Standardized } \\
\text { difference }\end{array}$ & Critical value & Pr $>$ Diff \\
\hline \multirow{3}{*}{ 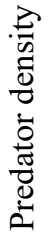 } & Four vs One & 0.168 & 14.270 & 1.962 & $<0.0001$ \\
\hline & Four vs Two & 0.101 & 8.553 & 1.962 & $<0.0001$ \\
\hline & Two vs One & 0.067 & 5.717 & 1.962 & $<0.0001$ \\
\hline \multirow{3}{*}{ 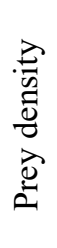 } & Ten vs Five & 0.032 & 2.726 & 1.962 & 0.006 \\
\hline & Ten vs Twenty & 0.006 & 0.497 & 1.962 & 0.619 \\
\hline & Twenty vs Five & 0.026 & 2.229 & 1.962 & 0.026 \\
\hline \multirow{3}{*}{ 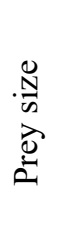 } & A vs $\mathrm{C}$ & 0.151 & 12.852 & 1.962 & $<0.0001$ \\
\hline & A vs B & 0.071 & 6.032 & 1.962 & $<0.0001$ \\
\hline & $\mathrm{B}$ vs $\mathrm{C}$ & 0.080 & 6.820 & 1.962 & $<0.0001$ \\
\hline
\end{tabular}

0.054 (mean $\pm \mathrm{SE}$ ) to $0.52 \pm 0.086$ for $P$. corneus and from $0.04 \pm 0.059$ to $0.3 \pm 0.071$ for I. exustus over the period of 24 hours (Figure 3 ) (for each prey species $\mathrm{N}=400$ observations; 2 levels of prey condition/ heterogeneity, 4 levels of habitat complexity $=8 * 50$ replicates for each combination). Although the consumption rate on $P$. corneus fluctuated among different conditions, the model parameters of the logistic regression [for P. corneus: prey consumed $(\mathrm{y})=1 /$ $(1+\exp (-(-5.78+0.11 *$ prey condition $-0.16 *$ habitat complexity)))] indicated that no significant difference is observed due to prey condition i.e. the heterogeneity of prey and habitat complexity (intercept, $\mathrm{a}=$
$-5.782 \pm 0.341 \mathrm{SE} ;$ Wald $\chi 2=287.929 ; \mathrm{P}<0.0001 ;$ prey condition, $\mathrm{b}_{1}=0.111 \pm 0.178 \mathrm{SE}$; Wald $\chi^{2}=$ $0.386 ; \mathrm{P}=0.534$; not significant; habitat complexity, $b_{2}=-0.156 \pm 0.08 ; P=0.052$; not significant). In contrast, the prey condition changed the predation on the $I$. exustus as indicated by the logistic regression [for I. exustus, (y) prey consumed $=1 /(1+\exp (-$ $(-5.1-0.764$ prey condition $+0.07 *$ Habitat $)))$ ] with the model parameters of the equation showing significant contribution of the prey condition (intercept, $\mathrm{a}=$ $-5.1 \pm 0.468 \mathrm{SE}$; Wald $\chi^{2}=118.861 ; \mathrm{P}<0.0001$; prey condition, $\mathrm{b}_{1}=0.764 \pm 0.265 \mathrm{SE}$; Wald $\chi 2=8.339$; $\mathrm{P}<0.0001$; habitat complexity, $\mathrm{b}_{2}=-0.073 \pm 0.111$; 


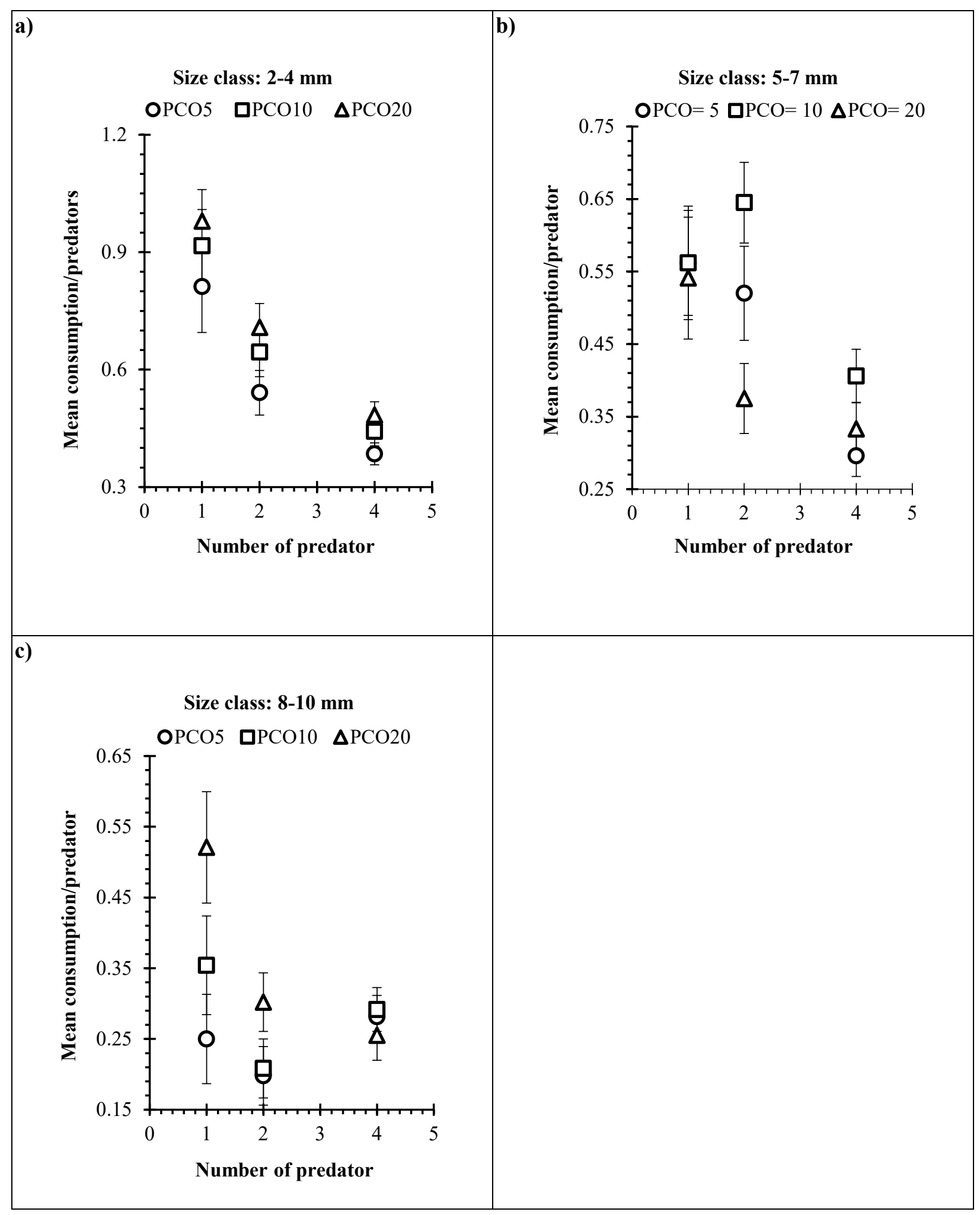

Figure 2(a-c). The per capita prey consumption by $G$. weberi (mean $\pm \mathrm{SE}$ ) in relation to the available density levels and size classes of $P$. corneus (PCO) (a through c) and the relative density of G. weberi (as the number of predator). The respective density of the prey is shown with the symbol, PCO5 represents 5 snails, PCO10 represents 10 snails and PCO20 represents 20 snails. 


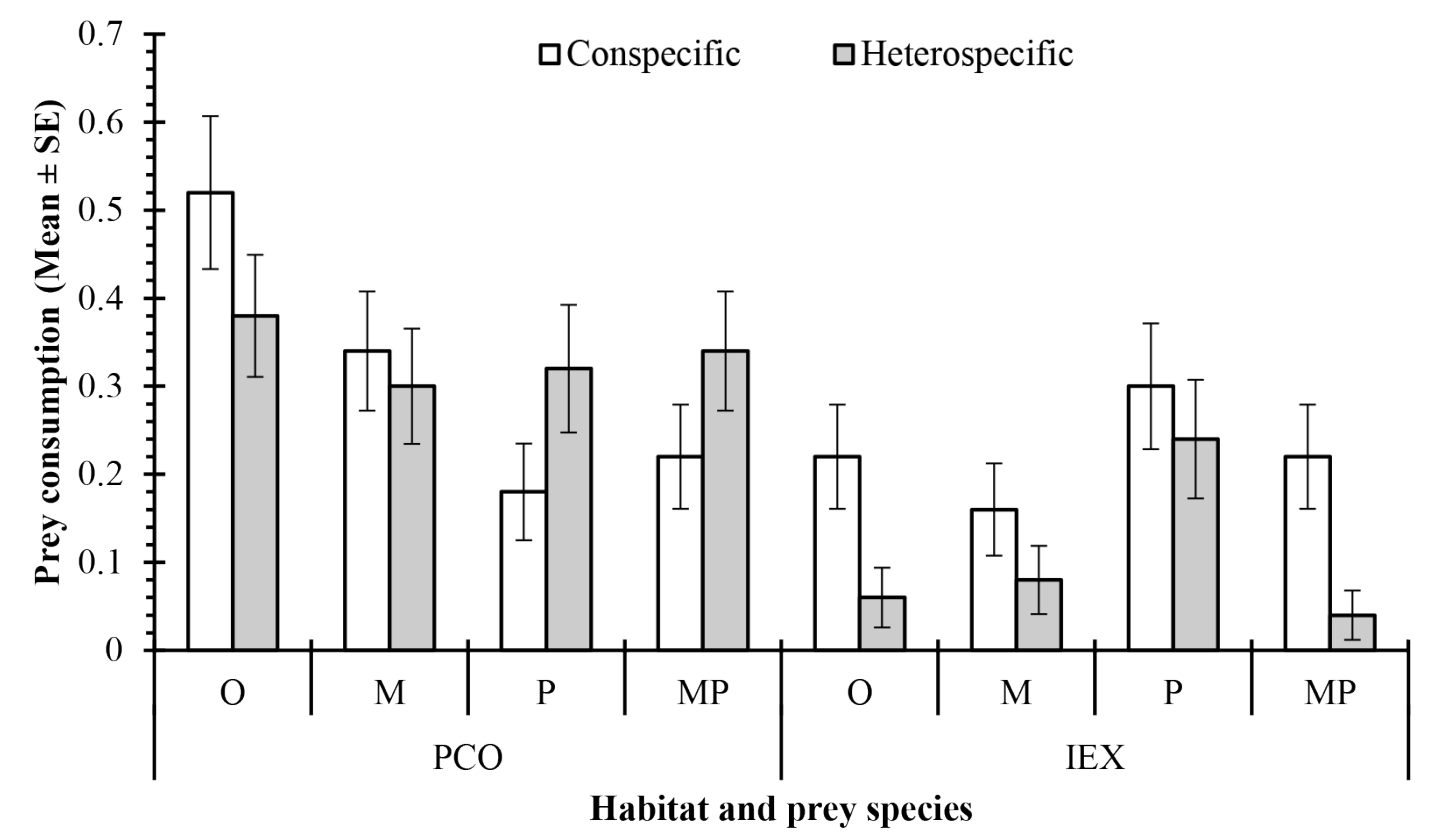

Figure 3. Comparative consumption (mean $\pm \mathrm{SE}$ ) in a $24 \mathrm{~h}$ period by G. weberi on P. corneus (PCO) and I. exustus (IEX) under prey conditions (conspecific and heterospecific prey) and different habitat conditions (O- open, M- macrophyte, P- pebbles and MP- both macrophyte and pebble containing habitats).

$\mathrm{P}=0.509$; not significant) in the variation in prey selection by the leech G. weberi when I. exustus is considered as a focal prey.

The selectivity index analysis shows that $G$. weberi preferred $P$. corneus significantly in open, $O$ ( $t$ value $=5.587, d f=20, P<0.0001)$, macrophytes, $M(t$ value $=3.801, d f=16, P=0.002)$ and macrophytes and pebbles $M P(t$ value $=5.457, d f=18$, $P<0.0001)$ habitats and avoided I. exustus. Only in pebbles, $P$ habitat, the leech showed no significant $(t$ value $=0.811, d f=24, P=0.425)$ preference on any of the prey snails (Figure 4 ).

\section{Discussion}

The results suggest that $G$. weberi is an effective predator of the exotic snail $P$. corneus, though the consumption decreased significantly with the increase in prey size. The prey consumption also varied with the relative density of the predator $G$. weberi and the prey $P$. corneus. Similar results were observed in case of the predation on invasive snail Physa acuta
(= Physella acuta) and Pomacea bridgesii (= diffu$s a$ ), but consumption rates varied with size classes of Ferrissia baconi when exposed to the same predator, G. weberi (Aditya \& Raut 2002a, 2004, 2005). However, the variations in the prey consumption pattern can be related to the prey identity, prey defense mechanisms and the predatory approach. For instance, the prey handling for the limpet $F$. baconi with univalve shell will be expectedly different from other snails. Likewise, the handling of the operculate snail $P$. bridgesii will be different from the planorbid snails I. exustus and P. corneus. The prey defense mechanism can also be a factor for inducing variations in the prey subduing and thus prey consumption of $G$. weberi. In the experimental set up, the search for the prey and the prey subduing by $G$. weberi may appear to be different from the natural conditions. In case of the leech, Helobdella conifera, the prey subduing varied with $P$. acuta and Bulinus tropicus as prey (Wilken and Appleton 1991). The prey snails namely, L. natalensis, B. tropiccus, P. acuta and A. marmora- 


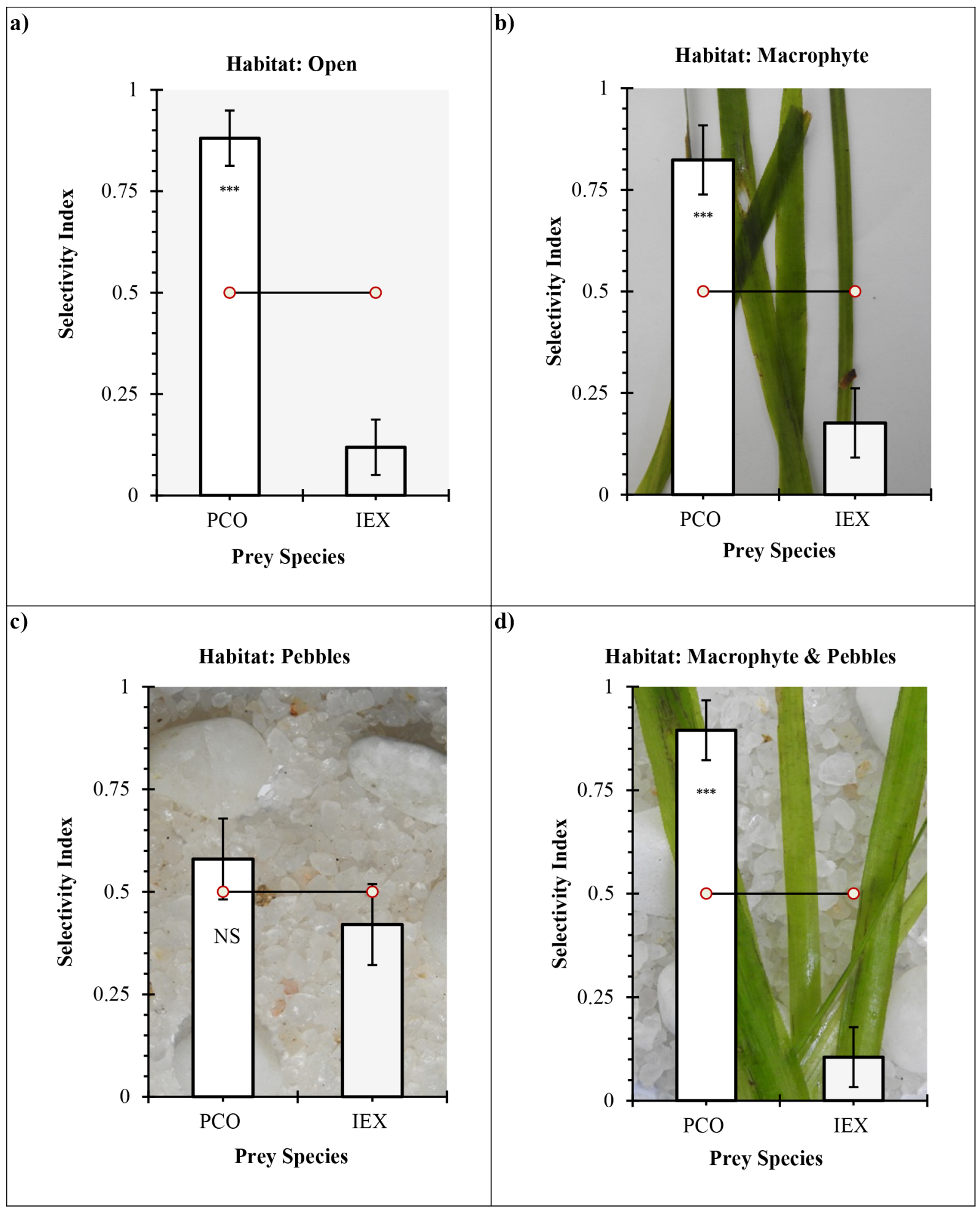

Figure 4. The prey selectivity index (mean $\pm \mathrm{SE}$ ) of $G$ weberi, against the native snail I. exustus (IEX) and exotic $P$. corneus (PCO) in (a) open, (b) macrophyte, (c) pebbles and (d) macrophyte and pebbles containing habitats. In each panel, the horizontal lines represent the null hypothesis of no preference or equal preference for both the species. Among the following graphs, the significant differences in the t-test are provided as $* * *$, representing $<0.001$ level. NS - not significant. 
ta also exhibited varied defense mechanisms when exposed to the predator $H$. conifera (Wilken and Appleton 1991). Similar observations on the differences in the antipredator behaviour by the snails $P$. acuta (= Physella acuta) and P. fontinalis against the leeches Glossiphonia complanata and Erpobdella octoculata (Krupski et al. 2018). In laboratory observation, it was apparent that as a predator of the snail Helisoma duryi, the leech Helobdella conifera could subdue small (4-7.5 mm in shell height) than the larger (10 $-13 \mathrm{~mm}$ shell height) snails, and thus consumed live small snails as well as scavenged flesh of dead large snails (Davies et al. 1997). In another study, it was observed that the leech, Whitmania laevis exhibits prey-size selection, reflected through consumption of the medium sized snails in operculated species like Pomacea canaliculata, Thiara tuberculata and Sinotaia quadrata. For the non-operculated species, Radix auricularia swinhoei and P. acuta, the large sized snails were consumed (Lai et al. 2011). Not only for $G$. weberi and other malacophagous leeches, but comparable predatory behaviour is also observed by the freshwater crayfish that preferred smaller over the larger snails (Nyström and Pérez 1998) as a strategy to overcome prey defence mechanism. In our experiment, the trend of higher consumption rate is toward smaller size classes, suggesting that $G$. weberi can cause a considerable effect on the population structure of $P$. corneus as the snails will be consumed before reaching the reproductive stage. It is evident in many studies that the handling time of predator is negatively related to the prey density (Tully et al. 2005; Cooper \& Anderson 2006; Wong \& Barbeau 2006), and, therefore predation rate may increase in dense prey population. In five out of nine experimental combinations, a similar outcome was observed in the present instance. The per capita mean consumption on $P$. corneus decreased with increasing predator density in smaller sizes of prey which indicates the possible presence of predator interference within the G. weberi population. Predator interference had been observed in natural and laboratory systems (Skalski \& Gilliam 2001; Kratina et al. 2009) and thought to be a major driving force of food-web stability and prey-predator interactions (van Voorn et al. 2008; Rall et al. 2008; Chakraborty \& Chattopadhyay 2011).

The prey selectivity and foraging behavior of a predator in a heterogenic community can be predicted by the cost-benefit function that maximizes the fitness of the predator (MacArthur \& Pianka 1966; Schoener 1971; Emlen 1975). The predator can increase their fitness by selectively predating upon the profitable resources, in particular depending on the prey size and nutrition content of prey. Many predators generally do not depend solely on a single prey but preferably consume others to balance their nutritional requirements (Mayntz et al. 2005). Such reflections of prey selection and preferences are known in leeches like Erpobdella octoculata (Kutschera 2003), Helobdella conifera (Davies et al. 1997), W. laevis (Lai et al. 2011), as well as in G. weberi (Aditya \& Raut 2005). Prey size is a prime predictor of prey selection (Boukal 2014), and the prey selection in $G$. weberi varied with the prey size reflected in the case of $P$. acuta and F. baconi as prey (Aditya \& Raut 2002a, 2004). In the present context, similar sizes of I. exustus and P. corneus were offered to G. weberi in the two prey experiment. Under such condition, the prey selectivity can be assumed to depend on the predator's foraging pattern and anti-predatory behaviour of prey. The glossiphoniid leeches do not swim under any set of conditions and randomly explore the habitat to search and attack prey, and predation success depends on the encounter rate and capture efficiency (Sawyer 1986; Brönmark \& Malmqvist 1986; Wilken \& Appleton 1991). The native snail I. exustus was observed to move over the pebbles for most of the time (Figure: 1e). Hence, in the habitat characterized by the presence of pebbles, the leech used the pebbles to refuge and attacked $I$. exustus with more proficiency. Despite the prey preference of $G$. weberi was slightly tilted towards $P$. corneus in the $P$ habitat, higher predation rate on $I$. exustus resulted in no significant prey preference but $G$. weberi showed significant prey preference towards non-native snail $P$. corneus in the remaining habitats. Shifting the prey preference of native predators towards exotic prey is a well-recorded phenomenon. For instance, a native predatory snail Stramonita haemastoma shifted its prey preference from indigenous prey to the invasive mussel Brachidontes pharaonis when abundant in the Israeli rocky shore (Rilov et al. 2002) and a native endangered fish Eucyclogobius newberryi used the invasive mud snail Potamopyrgus antipodarum as a novel food source in Big Lagoon, California, USA, which can wield substantial predation pressure upon the invasive snail (Hellmair et al. 2011).

The predation on both snails varied with different habitat complexities. As observed in the exper- 
iments, in $P$ habitat, the consumption on $I$. exustus was significantly higher compared to the other habitats but no difference was observed between the open and the rest. Contrarily, no significant consumption difference was observed for $P$. corneus amidst the complex habitats compared to the open habitat. Besides structural complexity, the predation rate on $P$. corneus did not differ significantly due to heterogenic compared to the conspecific prey conditions, but consumption on $I$. exustus decreased significantly. Such observation strengthens the view of the possibility of $G$. weberi in regulating the $P$. corneus population, in the presence of alternative prey. However, the identity of the alternative prey, relative density and types of alternative prey, as well as the availability of the refuge in the larger habitat conditions, may influence the interactions of the prey $P$. corneus and the malacophagous leech $G$. weberi.

The leech, G. weberi showed an entrancing behavior during the experiment. After consuming the body fluids of $P$. corneus, few of the leeches retracted their heads, twisted and shortened their bodies. Lai et al. (2011) observed similar behavior on a leech, Whitmania laevis, described that this kind of behavior can be resulted by physical injuries from the closing opercula of operculated snails. There was no chance of physical injuries of $G$. weberi as P. corneus is a non-operculated snail, but that particular behavior of leech can be caused by some toxic or indigestible molecules present within the prey. Pintor and Byers (2015) stated that depending on the nutritional value or palatability, invasive species can result in a positive, negative or neutral effect on native predators. In response to invasive species, the predators can reshape their behavioural strategies toward the prey. For instance, as invasive cane toads may cause illness or deaths to Australian predators, the predators learned to avoid the toxic prey (Greenlees et al. 2010; O’Donnell et al. 2010; Somaweera et al. 2011). Therefore, the behavioural adaptations of $G$. weberi and $P$. corneus can be studied over an extended time range.

Given the observations of the present study, the malacophagous leech $G$. weberi appears to be an efficient predator of the exotic snail P. corneus even in the presence of an indigenous prey, I. exustus. The preference exhibited by $G$. weberi suggests interference with the chance of establishment of the exotic snail $P$. corneus in the natural habitats in the Indian context. However, the efficacy of $G$. weberi may vary with the habitat conditions and with the presence of alternative prey. In situations where the alternative prey is other than I. exustus, like the lymnaeid snail L.lutoela (Raut and Nandi 1984) and the limpet $F$. baconi (Aditya \& Raut 2004), the prey consumption and thus the preference of $G$. weberi may vary, which needs to be evaluated further. The presence of invertebrate predators are often thought to have a trivial effect on macroinvertebrate abundance (Gathman 2020) but predatory diving beetles (Dytiscus alaskanus) caused alternation in the diving beetle-snailperiphyton trophic cascade (Cobbaert et al. 2010) and several predatory insects were observed to negatively impact gastropod density and biomass (Turner and Chislock 2007). Similarly, the effectiveness of the malacophagous leech in reducing the exotic snail population cannot be ruled out, though the prey preferences may be a strong factor in successful regulation. Therefore, further studies can be conducted to predict the vulnerability of non-native $P$. corneus under multiple native snail species and malacophagous predators.

\section{ACKNOWLEDGEMENT}

The constructive comments of two anonymous reviewers that helped in the enhancement of the manuscript are duly acknowledged. We are grateful to the Head, Department of Zoology, University of Calcutta, Kolkata, West Bengal, India for the facilities provided. PP acknowledges the financial support of CSIR-HRDG [09/028(1115)/2019-EMR-1, dated 06/08/2019].

\section{Corresponding Author}

*gautamaditya2001@gmail.com

\section{REFERENCES}

Addinsoft SARL. (2010) XLSTAT softwere, version 9.0. Paris: Addinsoft.

Aditya, G. \& Raut, S.K. (2001) Predation of water bug Sphaerodema rusticum Fabricius on the snail Pomacea bridgesi (Reeve), introduced in India. Current Science, 81(11), 1413-1414.

Aditya, G. \& Raut, S.K. (2002a) Potential of the leech Glossiphonia weberi (Blanchard) in controlling the sewage snails Physa acuta Draparnaud. Current Science, 83(11), 1317-1319.

Aditya, G. \& Raut, S.K. (2002b) Predation potential of the water bugs Sphaerodema rusticum on the sewage 
snails Physa acuta. Memórias do Instituto Oswaldo Cruz, 97(4), 531-534.

Aditya, G. \& Raut, S.K. (2002c) Predation of water bug Sphaerodema rusticum on the freshwater snails Lymnaea (Radix) luteola and Physa acuta. The Veliger, 45(3), 267-269.

Aditya, G. \& Raut, S. K. (2004) Glossiphonia weberi, an effective predator of the freshwater limpets Ferrissia baconi. Current Science, 87(2), 142-144.

Aditya, G. \& Raut, S.K. (2005) Feeding of the leech Glossiphonia weberi on the introduced snail Pomacea bridgesii in India. Aquatic Ecology, 39, 465-471.

Baltz, D.M. \& Moyle, P.B. (1993) Invasion resistance to introduced species by a native assemblage of California stream fishes. Ecological Applications, 3(2), 246-255.

Berrie, A.D. (1963) Life-cycle of Planorbarius corneus (L.). Nature, 198, 805-806.

Beukers, J.S. \& Jones, G.P. (1997) Habitat complexity modifies the impact of piscivores on a coral reef fish population. Oecologia, 114, 50-59.

Biswas, G. (1991) Snail borne diseases and their role in veterinary public health. In: Director, Zoological Survey of India (Ed.), Snails, Flukes and Man (pp. 73-78). Zoological Survey of India.

Boukal, D.S. (2014) Trait and size-based descriptions of trophic links in freshwater food webs: current status and perspectives. Journal of Limnology, 73, 171-185.

Brönmark, C. \& Malmqvist, B. (1986) Interactions between the leech Glossiphonia complanata and its gastropod prey. Oecologia, 69, 268-276.

Carlsson, N.O.L \& Lacoursiére, J.O. (2005) Herbivory on aquatic vascular plants by the introduced golden apple snail (Pomacea canaliculata) in Lao PDR. Biological Invasions, 7, 233-241.

Carlsson, N.O.L. \& Brönmark, C. (2006) Size-dependent effects of an invasive herbivorous snail (Pomacea canaliculata) on macrophytes and periphyton in Asian wetlands. Freshwater Biology, 51, 695-704.

Carlton, J.T. (2003) Community assemblage and historical biogeography in the North Atlantic Ocean: the potential role of human-mediated dispersal vectors. Hydrobiologia, 503, 1-8.

Chakraborty, S. \& Chattopadhyay, J. (2011) Effect of cannibalism on a predator-prey system with nutritional value: a model based study. Dynamical Systems, 26(1), 13-22.

Chang, A.L., Grossman, J.D., Spezio, T.S., Weiskel, H.W., Blum, J.C., et al. (2009) Tackling aquatic invasions: risks and opportunities for the aquarium fish industry. Biological Invasions, 11, 773-785

Chesson, J. (1978) Measuring preference in selective predation. Ecology, 59(2), 211-215.

Cobbaert, D., Bayley, S.E. \& Greter, J. (2010) Effects of a top invertebrate predator (Dytiscus alaskanus; Coleoptera: Dytiscidae) on fishless pond ecosystems. Hydrobiologia, 644, 103-114.

Cooper, W.E. \& Anderson, R. (2006) Adjusting prey handling times and methods affect profitability in the broad-headed skink (Eumeces laticeps). Herpetologica, 62(4), 356-365.

Costil, K. \& Daguzan, J. (1995a) Effect of temperature on reproduction in Planorbarius corneus (L.) and Planorbis planorbis (L.) throughout the life span. Malacologia, 36(1-2), 79-89.

Costil, K. \& Daguzan, J. (1995b) Comparative lifecycle and growth of two freshwater gastropod species, Planorbarius corneus (L.) and Planorbis planorbis (L.). Malacologia, 37(1), 53-68.

Cowie, R.H. (2002) Apple snails as agricultural pests: their biology, impacts, and management. In: Baker GM (Ed.) Molluscs as crop pests (pp. 145-192). CABI Publishing, Wallingford.

Crowl, T.A., Crist, T.O., Parmenter, R.R., Belovsky, G. $\&$ Lugo, A.E. (2008) The spread of invasive species and infectious disease as drivers of ecosystem change. Frontiers in Ecology and the Environment, 6, 238246.

Davies, R.W., McLoughlin, N.J. \& Oosthuizen J.H. (1997) The life-cycle and feeding of the African freshwater leech Helobdella conifera (Glossiphoniidae), South African Journal of Zoology, 32(1), 1-4.

Dobson, M. (2004) Replacement of the native freshwater snail by the exotic Physa acuta (Gastropoda: Physidae) in southern Mozambique; a possible control mechanism for schistosomiasis. Annals of Tropical Medicine and Parasitology, 98(5), 543-548.

Doherty, T.S., Glen, A.S., Nimmo, D.G., Ritchie, E.G. \& Dickman, C.R. (2016) Invasive predators and global biodiversity loss. Proceedings of the National Academy of Sciences, 113(40), 11261-11265.

Duggan, I.C. (2010) The freshwater aquarium trade as a vector for incidental invertebrate fauna. Biological Invasions, 12, 3757-3770.

Emlen, J.M. (1975) Optimal choice in diet: test of a hypothesis. The American Naturalist, 109, 427-435.

Estebenet, A.L. (1995) Food and feeding in Pomacea canaliculata (Gastropoda, Ampullariidae). Veliger, 38, 277-283. 
Gathman, J.P. (2020) Do predators structure wetland macroinvertebrate assemblages? different effects of mudminnows and dragonfly nymphs in field experiments. Wetlands, 40, 143-152.

Giller, P.S. \& McNeill, S. (1981) Predation strategies, resource partitioning and habitat selection in Notonecta (Hemiptera/Heteroptera). Journal of Animal Ecology, 50, 789-808.

Gillis, C. \& Chalifour, M. (2010) Changes in the macrobenthic community structure following the introduction of the invasive algae Didymosphenia geminata in the Matapedia River (Québec, Canada). Hydrobiologia, 647, 63-70.

Grabowski, J.H. (2004) Habitat complexity disrupts predator-prey interactions but not the trophic cascade on oyster reefs. Ecology, 85(4), 995-1004.

Greenlees, M., Phillips, B.L. \& Shine, R. (2010) Adjusting to a toxic invader: native Australian frog learns not to prey on cane toads. Behavioural Ecology, 21, 966-971.

Grosholz, E. (2002) Ecological and evolutionary consequences of coastal invasions. Trends in Ecology and Evolution, 17(1), 22-27.

Harris, L.A., Buckley, B., Nixon, S.W. \& Allen, B.T. (2004) Experimental studies of predation by bluefish Pomatomus saltatrix in varying densities of seagrass and macroalgae. Marine Ecology Progress Series, 281, 233-239.

Hellmair, M., Goldsmith, G. \& Kinziger, A.P. (2011) Preying on invasives: the exotic New Zealand mudsnail in the diet of the endangered tidewater goby. Biological Invasions, 13, 2197-2201.

Hosokawa, T., Nikoh, N. \& Fukatsu, T. (2014) Fine-scale geographical origin of an insect pest invading North America. PLoS ONE, 9(2), e89107.

Human, K.G. \& Gordon, D.M. (1996) Exploitation and interference competition between the invasive Argentine ant, Linepithema humile and native ant species. Oecologia, 105, 405-412.

Hurlbert, S.H. (1984) Pseudoreplication and the design of ecological field experiments. Ecological Monographs, 54(2), 187-211.

Kratina, P., Vos, M., Bateman, A. \& Anholt, B.R. (2009) Functional responses modified by predator density. Oecologia, 159, 425-433.

Kreps, T.A., Baldridge, A.K. \& Lodge, D.M. (2012) The impact of an invasive predator (Orconectes rusticus) on freshwater snail communities: Insights on habitat-specific effects from a multilake long-term study.
Canadian Journal of Fisheries and Aquatic Sciences, 69, 1164-1173.

Krupski, A., Karasek, T. \& Koperski, P. (2018) Differences between two physid species (Gastropoda: Physidae) in antipredator behaviour induced by leeches. Journal of Molluscan Studies, 84, 96 - 102.

Kutschera, U. (2003) The feeding strategies of the leech Erpobdella octoculata (L.): a laboratory study. International Review of Hydrobiology, 88(1): 94 - 101.

Kwong, K.L., Wong, P.K., Lau, S.S.S. \& Qiu, J.W. (2008) Determination of the distribution of apple snails in Hong Kong two decades after their initial invasion. Malacologia, 50, 293-302.

Lai, Y.T., Chen, J.H. \& Lee, L.L. (2011) Prey selection of a shell-invading leech as predicted by optimal foraging theory with consumption success incorporated into estimation of prey profitability. Functional Ecology, 25, 147-157.

Lieb, B., Dimitrova, K., Kang, H., Braun, S., Gebauer, W., Martin, A., et al. (2006) Red blood with blue-blood ancestry: Intriguing structure of a snail haemoglobin. Proceedings of the National Academy of Sciences, 103(32), 12011-12016.

MacArthur, R. \& Pianka, E. (1966) On Optimal Use of a Patchy Environment. American Naturalist, 100, 603-609.

Mack, R.N., Simberloff, D., Lonsdale, W.M., Evans, H., Clout, M. \& Bazzaz, F.A. (2000) Biotic invasions: causes, epidemiology, global consequences, and control. Ecological Applications, 10(3), 689-710.

Malek, E.A. \& Cheng, T.C. (1974) Medical and Economic Malacology. (Academic Press: New York.) Marine Ecology Progress Series, 329, 225-238.

Mayntz, D., Raubenheimer D., Salomon, M., Toft, S. \& Simpson, S. (2005) Nutrient-Specific Foraging in Invertebrate Predators. Science, 307(5706), 111-113.

Miranda, N.A.F. \& Perissinotto, R. (2014a) Benthic assemblages of wetlands invaded by Tarebia granifera (Lamarck, 1822) (Caenogastropoda: Thiaridae) in the iSimangaliso Wetland Park, South Africa. Molluscan Research, 34, 40-48.

Miranda, N.A.F. \& Perissinotto, R. (2014b) Effects of an alien invasive gastropod on native benthic assemblages in coastal lakes of the iSimangaliso Wetland Park, South Africa. African Invertebrates, 55, 209-228.

Miranda, N.A.F., Perissinotto, R. \& Appleton C.C. (2011) Population structure of an invasive parthenogenetic gastropod in coastal lakes and estuaries of Northern KwaZulu-Natal, South Africa. PLoS ONE, 6, e24337. 
Ng, T.H., Tan, S.K., Wong, W.H., Meier, R., Chan, S-Y., Tan, H.H., et al. (2016) Molluscs for Sale: Assessment of Freshwater Gastropods and Bivalves in the Ornamental Pet Trade. PLoS ONE, 11(8), e0161130.

Nyström, P. \& Pérez, J.R. (1998) Crayfish predation on the common pond snail (Lymnaea stagnalis): the effect of habitat complexity and snail size on foraging efficiency. Hydrobiologia, 368, 201-208.

O’Donnell, S., Webb, J.K. \& Shine, R. (2010) Conditioned taste aversion enhances the survival of an endangered predator imperilled by a toxic invader. Journal of Applied Ecology, 47, 558-565.

Paini, D.R., Sheppard, A.W., Cook, D.C., De Barro, P.J., Worner, S.P. \& Thomas, M.B. (2016) Global threat to agriculture from invasive species. Proceedings of the National Academy of Sciences, 113(27), 7575-7579.

Parveen, S., Karmakar, R., Paul, P., Banerjee, S., Barman, H. \& Aditya, G. (2019) Shell morphometry and fecundity of the exotic snail Planorbarius corneus (Linnaeus, 1758) (Gastropoda: Planorbidae) In Kolkata, India. Uttar Pradesh Journal of Zoology, 40(4), 236-244.

Pintor, L.M. \& Byers, J.E. (2015) Do native predators benefit from non-native prey? Ecology Letters, 18, 1174-1180.

Rall, B.C., Guill, C. \& Brose, U. (2008) Food-web connectance and predator interference dampen the paradox of enrichment. Oikos, 117, 202-213.

Raut, S.K. \& Nandi, R. (1984) Experimental studies on effectiveness of the predatory leech, Glossiphonia weberi in the biological control of vector snail Lymnaea luteola. Bulletin of Zoological Survey of India, 6(1-3), 5-19.

Raut, S.K. (1981) Population interactions among freshwater snails. Proceedings of the Symposium of Ecology and Animal Population, Zoological Survey of India, 2, 163-173.

Raut, S.K. \& Barker, G. M. (2002) Achatina fulica Bowdich and other Achatinidae as pests in tropical agriculture. In: Barker, G.M. (ed.): Molluscs as crop pest (pp. 55-114). CAB International, Wallingford, UK.

Rehage, J.S., Barnett, B.K. \& Sih, A. (2005) Foraging behavior and invasiveness: do invasive Gambusia exhibit higher feeding rates and broader diets than their noninvasive relatives? Ecology of Freshwater Fish, 14, 352-360.

Rilov, G., Figueira, W.F., Lyman, S.J. \& Crowder, L.B. (2007) Complex habitats may not always benefit prey: linking visual field with reef fish behavior and distribution. Marine Ecology Progress Series, 325, 225-238.

Rilov, G., Gasith, A. \& Benayahu, Y. (2002) Effect of an exotic prey on the feeding pattern of a predatory snail. Marine Environmental Research, 54(1), 85-98.

Rixon, C.A.M., Duggan, I.C., Bergeron, N.M.N., Ricciardi, A. \& Mac-Isaac, H.J. (2005) Invasion risks posed by the aquarium trade and live fish markets to the Laurentian Great Lakes. Biodiversity and Conservation, 14, 1365-1381.

Sangwan, A.K., Jackson, B., de Galnville, W., Pfeiffer, D. U. \& Stevens, K. B. (2016) Spatial analysis and identification of environmental risk factors affecting the distribution of Indoplanorbis and Lymnaea species in semi-arid and irrigated areas of Haryana, India. Parasite Epidemiology and Control, 1(3), 252-262.

Sanders, N.J., Gotelli, N.J., Heller, N.E. \& Gordon, D.M. (2003) Community disassembly by an invasive species. Proceedings of the National Academy of Sciences, 100(5), 2474-2477.

Sawyer, R.T. (1986). Leech Biology and Behaviour. Oxford University Press.

Schoener, T.W. (1971) Theory of feeding strategies. Annual Review Ecology, Evolution, and Systematics, 11, 369-404.

Seddon, M.B. \& Van Damme, D. (2011) Planorbarius corneus. The IUCN Red List of Threatened Species, e.T156083A4889234.

Skalski, G.T. \& Gilliam, J.F. (2001) Functional responses with predator interference: viable alternatives to the Holling type II mode. Ecology, 82, 3083-3092.

Somaweera, R., Webb, J.K., Brown, G.P. \& Shine, R. (2011) Hatchling Australian freshwater crocodiles rapidly learn to avoid toxic invasive cane toads. Behaviour, 148, 501-517.

Stoner, A.W. (1982) The influence of benthic macrophytes on the foraging behaviour of pinfish, Lagodon rhomboids (Linnaeus). Journal of Experimental Marine Biology and Ecology, 58, 271-284.

Su, S., Cassey, P. \& Blackburn, T.M. (2016) The wildlife pet trade as a driver of introduction and establishment in alien birds in Taiwan. Biological Invasions, 18, 215-229.

Tully, T., Cassey, P. \& Ferrière, R. (2005) Functional response: rigorous estimation and sensitivity to genetic variation in prey. Oikos, 111, 479-487.

Turner, A.M. \& Chislock, M.F. (2007) Dragonfly predators influence biomass and density of pond snails. Oecologia, 153, 407-415. 
van Voorn, G.A.K., Stiefs, D., Gross, T., Kooi, B.W., Feudel, U. \& Kooijman, S.A.L.M. (2008) Stabilization due to predator interference: Comparison of different analysis approaches. Mathematical Biosciences and Engineering, 5, 567-583.

Wesselingh, F.P., Cadeé, G.C. \& Renema, W. (1999) Flying high: On the airborne dispersal of aquatic organisms as illustrated by the distribution histories of the gastropod genera Tryonia and Planorbarius. Geologie en Mijnbouw, 78, 165-174.

Wilcove, D.S., Rothstein, D., Dubow, J., Phillips, A. \& Losos, E. (1998) Quantifying threats to imperilled species in the United States. BioScience, 48(8), 607615.

Wilken, G.B. \& Appleton, C.C. (1991) Avoidance responses of some indigenous and exotic freshwaler pulmonate snails to leech predation in South Africa. South African Journal of Zoology, 26, 6-10.

Wong, M.C. \& Barbeau, M.A. (2006) Rock crab predation of juvenile sea scallops: the functional response and its implications for bottom culture. Aquaculture International, 14, 355-376.

Young, J.O. \& Ironmonger, J.W. (1980) A laboratory study of the food of three species of leeches occurring in British lakes. Hydrobiologia, 68, 209-215.

Zar, J.H. (1999). Biostatistical analysis. Pearson Education India Singapore Pvt. Ltd., Indian branch.

Zhao, W. (2013) The great ramshorn (Planorbarius corneus): a new favourite in aquarium. Aquarium, 128133. (In Chinese).

Zotin, A.A. (2018) Individual growth of Planorbarius corneus (Planorbidae, Gastropoda) in postlarval ontogenesis. Russian Journal of Developmental Biology, 49(6), 381-387. 